\title{
Improving Food Security Through Conservation of the Mau Ecosystem in Narok County, Kenya
}

\author{
Stellah Malaso Koini* Godrick M Bulitia \\ School of Nursing, Maasai Mara University, PO BOX 861-20500, Narok, Kenya
}

\begin{abstract}
The world is experiencing intense hunger; Food production is becoming less each day as global populations continue to grow. Mau and other ecosystems destruction have increased global climate change. The only remaining approach to food security sustenance is conservation of ecosystem globally. Kenya in the year 2017 had declared drought a national disaster with half of the country experiencing intense draught. Recently the Kenyan government has put more effort by issuing a gazette notice to stop any forest degradation activity. The study purpose is to close the gap left by other studies on the effectiveness increasing forest cover towards improved food security. The study also compares approaches used by different countries to mitigate against the destruction of ecosystem while ensuring adequate food production for growing population. The study employed descriptive survey design. The target population were 100 respondents. The study found out ways to ensure healthy population through sustainability of food production, while conserving ecosystems in the rising global climate change. The study took into consideration the Mau ecosystems in Narok, Kenya. Quantitative and qualitative approaches in data collection, analysis and presentations were adopted. Data was analyzed using SPSS Version 20 and presented using frequencies and percentages. The study main findings and conclusions has unmasked several challenges experienced in conservation, restoration and protection of the Mau ecosystem. The major recommendation drawn from this Research shows that human activities in the ecosystem, directly and indirectly, contributes to decline in food security, with major implications for people's livelihoods and wellbeing, particularly for the poor.
\end{abstract}

Keywords: Food security, Mau ecosystems, Narok County, Population, Food production.

DOI: $10.7176 / \mathrm{JBAH} / 9-22-03$

Publication date: November $30^{\text {th }} 2019$

\section{Introduction}

The destruction of ecosystems has been in the rapid increase in Africa. This has been due to increased population, therefore this changes have had adverse negative effect on weather and climatic changes. The most significant impact of climate change is the potential to increase food insecurity and malnutrition. According to WFP (2015), 702 million people still live in extreme poverty and 793 million on state of food insecurity and extremely undernourished. People living in in dry land ecosystems of Sub-Saharan Africa and Kenya in particular, continue to struggle with hunger, frequent famines and associated consequences such as morbidity and mortality rates going higher, (Wambua 2014).Increased draught, floods and storms has always translated to food insecurity. Harsh weather has also led destruction or reduced crop production,destruction of road terrain, community assets and deteriorating livelihoods. (Tim Wheeler et al 2013). Exacerbating povertyand hunger which has been repetitive year in year out is a threat to lives and livelihoods.Undernutrition which is a precipitate of food insecurity has been shown to be the underlying cause of 3.5 million child deaths every year, and at least $35 \%$ of disease burden in children younger than 5 years. Maternal undernutrition increase the risk of maternal deaths at birth and $20 \%$ of maternal mortality.

Studies in Bangladesh, Ethiopia and Niger shows increased malnutrition in children under five, this is especially after floods or draught. Children born during draught are more likely to be undernourished. (WHO 2013). Estimates that by 2050 child malnutrition could rise by $20 \%$ as result of climate change.

\section{Key points}

Climate change and destruction of ecosystems affects food insecurity by intensifying poverty. Low education level in Kenya.

The Government should introduce draught resistant trees and food crops that respond differently to climate change.

The government should develop effective policies to ensure protection of ecosystems at the same time ensuring a food secure Country.

Finally farmers should adopt appropriate adaptive measures to curb the adverse effect of climate change on agribusiness.

Food Insecurity in Kenya

10 million people are food insecure with majority of them living on food relief. The current food insecurity being attributed to several factors, including frequent draughts in most parts of the country. The draught aggravation has 
been expounded by massive destruction of ecosystems in the country, Mau forest not been an exception. It's of great concern if a country with so much potential to agriculture continue to be food insecure and losing its citizen to hunger yet there is an alternative solutions. The recent catastrophic natural disasters in the country could have been avoided if there was enough forest cover, some much losses have been experienced include displacement in of people Tana River, Kilifi, Muranga, Mau and many other parts of the country. The world food programme (2011) have stated that this climatic changes have threaten to significantly exacerbate people at risk of hunger and under-nutrition.

Change in crop yields have been adversely affected by change in climate change and increased in temperature levels. Kenya is likely to suffer severe food security by the year 2100 unless farmers mitigate and undertake adaptation measures against climate change. The simulation results support other results that have shown that global warming will damage crop production.

The results of this research point at the need for policies that safeguard agriculture against the adverse effects of climate change in order to alleviate food insecurity. Mitigation against global warming can take two forms. Reduction of human emission of greenhouse gases and increasing capacity of carbon sinks through reforestation. Though Kenya contributes less to increased greenhouse gas emissions, a bigger role in mitigation can be done by encouraging reforestation throughout the country. This especially important in arid and semi-arid areas where draught resistant trees and food crops could be introduced. According to Thorlakson and Neufeldt (2012), states that agro-forestry increased farm productivity. The government should support affected Counties by ensuring effective policies to climate change. Adaptive measures to climate change should be introduced to farmers who may not always be aware that options are available to them. The Country should further intensify water harvesting particularly in dry areas. Countries like Israel and United Arab Emirates have adopted to using recycled water in irrigation. It's unfortunate that a Country that experiences so much rain twice a year also experience severe draughts. The study takes into account household-level characteristics and other factors that could affect the response of food insecurity to climate change. Future research studies should also take into consideration the use of other development domains that uses fast growing fruit trees, adaptive trees and use of stored harvested water for irrigation. Explore other studies to find out alternative livelihoods to use of trees and its products. The government should develop effective policies to ensure protection of ecosystems at the same time ensuring a food secure Country. Finally farmers should adopt appropriate adaptive measures to curb the adverse effect of climate change on agribusiness. There is need for further research in the area as this the backbone to feeding the world.

\subsection{Planting trees}

Over half of the respondents $62 \%$ said they faced challenges in restoration of the forests as rains was not sufficient to water the seedlings as the area is semi-arid. "Most of the time in the year it's very dry, making it difficult for the trees to thrive," said one female respondent. This was actually supported by $28 \%$ of the respondent. Unlike the recent rains all over the country the previous years, Narok County has experienced draught episodes for the past three years. Unlike 2018 where massive tree planting has been observed. One of the workers at forest tree planting nursery said that in the year 2018 they have sold three times seedlings than the three previous years combined. He attests this to the government directive and prolonged draughts that has escalated hunger and in the area. Another respondent said that, the community lacks awareness on the importance of tree planting but further stressed on lack of rain as the major obstacle. It's therefore important to make everyone participate in forest conservation. Although rain may fail at certain time of the year the watering of trees should be an alternative. Planting the adaptive seedlings that can withstand the dry climatic conditions with increase consultation with ministry of forestry and agriculture to find alternative seedlings to farmers, this can also be done through provision of seedlings to farmers. Relocation of individuals living the water catchment area of ecosystem to avoid deforestation is another alternative.

\section{Restoration of forests and Food security}

According to the respondent the best action to food security in the County and Country at large is planting of trees. "This will be done by encouraging farmers to plant trees in their land," said one of the respondents. Further increase in surveillance of the Mau to discourage tree cutting activities. The national government should team up with the County government to prevent logging, they should place strict measures to govern cutting down indigenous and exotic trees. Further youth activities in creation of awareness of the importance of conservation activities should be encouraged. This can be done by community organization once a month set a date for tree planting," says one respondent. Planting trees that increase forest cover at the same time providing fruits as alternative. This will be important as fruits provide nutrients that help prevention of malnutrition.

\section{Government restoration of $10 \%$ forest cover}

Although the government has so much tried to mitigate on tree planting the impact has not been fully achieved as tree cover is still at 7\%; this according to the ministry of forests. $43 \%$ said that the government is not committed 
in restoration of the forests while $30 \%$ said the government is committed, $7 \%$ were not aware. "The chances of food shortage will be minimal since there will be enough rain and people will plant food crops, said one respondent. The government has severally used a lot of money in export of food due to dry episode and due losses in farming. Malnutrition has been experienced in places where forest cover is minimal therefore it's the government mandate to be strict to ensure minimal wage bill in the sector. Senior government officials found guilty in deforestation should be severely punished. It's with great importance that everyone should participate in environmental conservation as the country depends entirely on Mau ecosystem, said another participant. The government should relocate all farming activities from Mau to lower part of the ecosystem. This should actually be in reality because the study was able to highlight that most of the politicians have used the Mau ecosystem for their own mileage.

\section{Media role}

The media according to the respondent has mobilized the restoration of Mau ecosystem by $56 \%$. They have highlighted the destruction on national Television and Radio. The local dialects have also educated the community on the importance of conservation of forest. They have also assisted in mobilization and planting of trees. "Advocacy should be done on the importance of tree planting by all the stakeholders and especially those living along the Mau ecosystem," said another respondent. The media has severally highlighted the dangers of deforestation and bringing stakeholders on board to discuss the demerits of forest destruction to the ecosystem. The media should be an independent entity and not be used as political tool in environment encroachment to suit politician's needs.

\section{Community activities}

The best and actually the only way to increase more forest cover is increase is planting of new trees. One respondent said that the government should put forward policies that prevent farming and grazing activities in government gazette forest, this because they believe that actually deforestation starts when people are allowed to do some activities near the water towers hence finally they allow themselves to settle in reserved land and forest. A fee should be introduced to discourage any farm activities and any human traffic in the area. Animal grazing was also see as a way of forest deterioration as charcoal burning was practiced by the same herders. The government should be in forefront in finding alternative to livelihood. In this analysis it was highlighted that alternative livelihoods such as using biogas instead of charcoal should be encouraged. There are already conservation initiative in place therefore the study found out that stagnation has been there due lack of all stakeholders involvement.

\section{Study area}

Consist of Mau Canopy is in the Rift valley of Kenya. It is the largest indigenous forest in East Africa, Covers 675,000 acres. Large parts of the forest have been cleared for settlement.

\section{Methodology}

A descriptive survey study was employed to determine the cycle of food security and health by those depending on ecosystem. The target population was 100 respondents.

\section{Results and Discussion}

Social-economic and Demographic characteristics

The female participants in the study were $60 \%$ while the male participants were $40 \%$. Among them the highest percentage $42 \%$ were between the ages $40-49$ years, 35\% between $18-28$ years, $19 \%$ were $29-39$ and $3 \%$ were 50 60 years, the lowest were above $60 \%$ at $1 \%$. Over half $57 \%$ in the study have tertiary education, those with primary education is as low $7 \%, 17 \%$ primary education and $19 \%$ had secondary education. Education level among women was lower than that of men as majority women $51 \%$ have no formal education. The primary food provider in most families was fathers $69 \%$ and mothers $31 \%$. And most of the food in the household was bought $75 \%$ only $25 \%$ get their food from their farms. The household income of the majority is above half $60 \%$. 


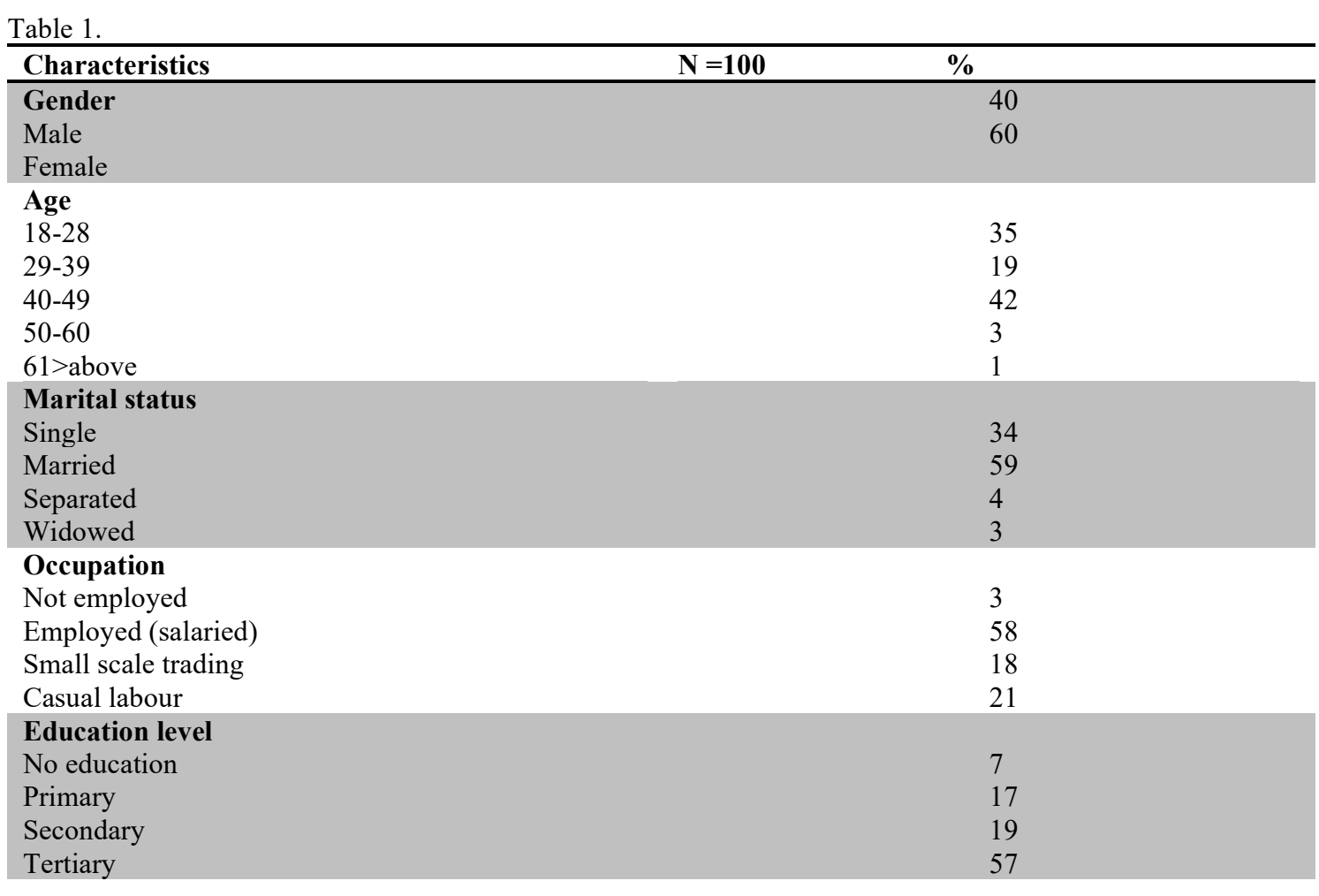

Table 2. Source of water

\begin{tabular}{lc}
\hline & Percent $\%$ \\
\hline River & 32.0 \\
Water tap & 62.0 \\
Borehole & 1.0 \\
Tanker & 5.0 \\
Total & 100.0 \\
\hline
\end{tabular}

Many participants in the household said that water is still not available at $86 \% .48 \%$ admitted to have experienced food insecurity while over half $52 \%$ did not experience food insecurity. $40 \%$ received food donations while $60 \%$ did not receive. Higher $75 \%$ have access to nutritious foods while $25 \%$ did not. $98 \%$ of the study participants believe that the only way to improve food security is through planting of trees and conservation of the ecosystem. The $2 \%$ were against tree planting as they could not eat trees. The same percentage believes $98 \%$ still food crops plantation can reduce food insecurity. Majority $97 \%$ of the participants depends on Mau ecosystem for their livelihoods and $96 \%$ have experienced drying of rivers. Over half $58 \%$ have participated in conservation of Mau ecosystem while $42 \%$ did not conserve yet they have indirectly or directly used the ecosystem. $19 \%$ of the community did participate in conservation of the ecosystem while $81 \%$ did not participate. Politicians according to the participants have actually contributed to $68 \%$ of Mau forest conservation. $32 \%$ said politicians did not contribute to forest conservation. $87 \%$ believe relocation of people from Mau ecosystem will give a solution to conservation of ecosystem and all participants believe water shortage can be reduced by planting trees. 
Table 3. Descriptive Statistics

\begin{tabular}{|c|c|c|c|c|c|c|}
\hline & $\mathrm{N}$ & Range & M & & $\begin{array}{c}\text { Std. } \\
\text { Deviation } \\
\end{array}$ & Variance \\
\hline & Statistic & Statistic & Statistic & $\begin{array}{l}\text { Std. } \\
\text { Error }\end{array}$ & Statistic & Statistic \\
\hline Marital status & 100 & 3.00 & 1.7600 & .06685 & .66848 & .447 \\
\hline Occupation & 100 & 3.00 & 2.5700 & .08558 & .85582 & .732 \\
\hline Occupation of partner & 69 & 3.00 & 2.0000 & .14452 & 1.20049 & 1.441 \\
\hline Education level & 100 & 3.00 & 3.2600 & .09808 & .98083 & .962 \\
\hline Household size & 100 & 5.00 & 2.8700 & .06913 & .69129 & .478 \\
\hline No of children & 96 & 3.00 & 1.8646 & .06886 & .67465 & .455 \\
\hline Source of family income & 100 & 3.00 & 2.3800 & .12853 & 1.28535 & 1.652 \\
\hline How is food obtained & 100 & 1.00 & 1.7500 & .04352 & .43519 & .189 \\
\hline Food provider & 100 & 1.00 & 1.3100 & .04648 & .46482 & .216 \\
\hline HH income percentage & 100 & 2.00 & 1.6200 & .08261 & .82609 & .682 \\
\hline Source of water & 100 & 5.00 & 1.8900 & .10626 & 1.06263 & 1.129 \\
\hline Is water sufficient & 100 & 1.00 & 1.8600 & .03487 & .34874 & .122 \\
\hline Is water available & 98 & 1.00 & 1.8061 & .04014 & .39737 & .158 \\
\hline Do you experience food insecurity & 100 & 1.00 & 1.5200 & .05021 & .50212 & .252 \\
\hline Have you received food donations & 100 & 1.00 & 1.6000 & .04924 & .49237 & .242 \\
\hline Do you have access to nutritious food & 100 & 1.00 & 1.2500 & .04352 & .43519 & .189 \\
\hline $\begin{array}{l}\text { Can we reduce food insecurity by planting } \\
\text { trees }\end{array}$ & 100 & 1.00 & 1.0200 & .01407 & .14071 & .020 \\
\hline $\begin{array}{l}\text { Can we reduce food insecurity by planting food } \\
\text { crops }\end{array}$ & 100 & 1.00 & 1.0200 & .01407 & .14071 & .020 \\
\hline Do you live near Mau ecosystem & 100 & 1.00 & 1.0300 & .01714 & .17145 & .029 \\
\hline Have you experienced drying of rivers & 100 & 1.00 & 1.0400 & .01969 & .19695 & .039 \\
\hline $\begin{array}{l}\text { Have you participated in conservation of Mau } \\
\text { ecosystem }\end{array}$ & 100 & 1.00 & 1.4200 & .04960 & .49604 & .246 \\
\hline Do you use Mau ecosystem & 100 & 1.00 & 1.5800 & .04960 & .49604 & .246 \\
\hline $\begin{array}{l}\text { Does community participate in conservation of } \\
\text { Mau ecosystem }\end{array}$ & 100 & 1.00 & 1.8100 & .03943 & .39428 & .155 \\
\hline $\begin{array}{l}\text { Do politicians participate in conservation of } \\
\text { Mau ecosystem }\end{array}$ & 100 & 1.00 & 1.3200 & .04688 & .46883 & .220 \\
\hline $\begin{array}{l}\text { Do you think we can reduce water shortage by } \\
\text { planting trees }\end{array}$ & 100 & .00 & 1.0000 & .00000 & .00000 & .000 \\
\hline $\begin{array}{l}\text { Is relocation of people living in Mau ecosystem } \\
\text { a solution }\end{array}$ & 91 & 1.00 & 1.0440 & .02161 & .20613 & .042 \\
\hline Age & 100 & 4.00 & 2.1600 & .09819 & .98186 & .964 \\
\hline Valid N (list wise) & 63 & & & & & \\
\hline
\end{tabular}

\section{Conclusion}

The latest scientific evidence suggests that changes in climate will exacerbate existing threats to food security. In this research on the study area found out that the area has perennially experienced food insecurity hence parts of the County been gazetted as hardships zone. Mau ecosystem has been in the limelight due its destruction reaching extreme heights. Although there have been strategies to curb food security by either planting draught resistant food crops this has not gone aboard in eradicating food insecurity. Moreover planting of trees and conservation of ecosystem has been a friendly and effective way to bring back climatic changes back to normal hence achieving better harvest for food secure country. All studies emphasized the negative effects of climate change on food security.

\section{The Kenyan government initiative}

The Kenyan government commissioned a task force to review forestry management following a declaration of three-month moratorium on logging, the task force recommended establishment of caretaker management team. The Chairperson Green belt movement Marion Kamau recommended prosecution of Kenya Forests Service (KFS) Officials culpable of mismanaging forests. She further recommends review of forest zoning to establish a core 
conservation zone to be surrounded by multiple user buffer zones, the width of which should not exceed 500 metres.

The Kenyan, Deputy President William S. Rutto said that the government is committed in ensuring that conservation of ecosystem was a reality. He further said that the government will enlist the services of National Youth Services in an aggressive exercise geared towards replanting indigenous trees for at least three years. This will go a long way in supplementing the ongoing tree planting campaign, whose target is to have the Country's forest cover regenerate. The taskforce was tasked with determining the scale of illegal logging, destruction, degradation and encroachment of public and community forests, water towers and other catchment areas: Reviewing the procedures, qualification and conditions for licensing of saw millers to determine their adequacy, fairness and appropriateness. Contributors to inter-governmental panel on climate change (IPCC) states that there has been limited research into impact of climate change on food security.

\section{References}

1. Ade Freeman, H., \& Omiti, J.M. (2003). Fertilizer use in semi-arid areas of Kenya: Analysis of smallholder farmers' adoption behavior under liberalized markets. Nutrient cycling in Agroecosystems, 66 (1), 23-31.

2. Arndt C., W. Farmer, K. Strzepek, and J. Thurlow. (2011). Climate Change, Agriculture and Food Security in Tanzania. UNU-WIDER Working Paper No. 2011/52.

3. Black, Robert; Laxminarayan, Ramanan; Temmerman, Marleen; Walker, Neff. 2016. Disease Control Priorities, Third Edition: Volume 2. Reproductive, Maternal, Newborn, and Child Health. Washington, DC: World Bank. (C) World Bank. https://openknowledge.worldbank.org/handle/10986/23833 License: CC BY 3.0 IGO.

4. Bouët, Antoine, ed.; and Laborde Debucquet, David, ed. 2017. Agriculture, development, and the global trading system: 2000 - 2015. Washington, D.C.: International Food Policy Research Institute (IFPRI). https://doi.org/10.2499/9780896292499.

5. Bruce M. Campbel.; Sonja J. Vermeulen, Pramod K Aggarwal, Caitlin Corner-Doll off, Evan Girvetz, Anna Maria Loboguerro, Julian Ramirez Villegaz, Todd Rosestock, Leocadio Sebastian, Philip K. Thornton, Eva Wollenberg. (2016). Reducing Risks to food security from climate change. Vol 11.

6. Braimoh, Ademola; Manyena, Bernard; Obuya, Grace; Muraya, Francis. (2018). Assessment of Food Security Early Warning Systems for East and Southern Africa. Africa Climate Business Plan Series;. World Bank, Washington, DC. (C) World Bank. https://openknowledge.worldbank.org/handle/10986/29269 License: CC BY 3.0 IGO.

7. Daily nation, July 22, 2008: Selfish interests threaten Mau forest.

8. Ecker, Olivier; Al-Riffai, Perrihan; Breisinger, Clemens; and El-Batrawy, Rawia. 2016. Nutrition and economic development: Exploring Egypt's exceptionalism and the role of food subsidies. Washington, D.C.: International Food Policy Research Institute (IFPRI). http://dx.doi.org/10.2499/9780896292383

9. Emmah, Mwangi; Droughts in the GHA: a case study of the 2010/2011drought in Kenya

10. FAO (2006). Food Security. Policy Brief, issue 2.

11. FAO (2008). The state of food insecurity in the world: High food prices and food security threats and opportunities, Food and Agricultural Organization of the United Nations, Rome.

12. FAO (2011). The state of food insecurity in the world. How does international price volatility affect domestic economies and food security?

13. FAO/ WFP (2010). The state of food Insecurity in the world: Addressing food insecurity in protracted crises, Food and Agriculture Organization of the United Nations (FAO); United Nations World Food Programme (WFP), Rome.

14. Herrero, M., C. Ringler, J. van de Steeg, P. Thorton et al. (2010). Kenya: Climate variability and Climate Change and their Impacts on the Agricultural Sector. Washington D.C.: IFPRI.

15. Fischer G. (2009). World Food and Agriculture to 2030/50: 'How do climate change and bioenergy alter the long-term outlook for food, agriculture and resource availability?' Food and Agriculture Organization of the United Nations. Economic and Social Development Department

16. Full transcript of the keynote speech by PIM Director Karen Brooks at the Crawford Fund's Annual Conference waste not, want not: the circular economy to food security" held on 29-30 August 2016 in Canberra, Australia.

17. http://www.pbl.nl/sites/default/files/cms/publicaties/PBL_2012_Exploring\%20food\%20s ecurity_555075001_0.pdf

18. IPCC (2012). Managing risks of extreme events and disasters to advance climate change adaptation. A special report working groups 1 and 11 of the intergovernmental panel on climate change. Accessed through. https://www.science direct.

19. Kabubo-Mariara, J. (2012). Institutional Isolation, Soil Conservation and Crop Productivity: Evidence from Machakos and Mbeere Districts in Kenya. African Journal of Social Sciences 2(3): 1-26. 
20. Knight A. T; Campbell B.M, Knowing but not doing: Selecting Priority conservation areas and the researchimplementation gap (2008). Conservation. Biol, 22 (2008), PP.610-617.

21. Online https://www.the.star.co.ke.

22. Molly E. Brown, Edward R. Carr, Kathryn L. Grace, Keith Wiebe, Christopher C. Funk, Witsanu Attavanich, Peter Backlund, Lawrence Buja. Do markets and trade help or hurt the global food system adapt to climate change? Food Policy, Volume 68, April 2017, Pages 154-159,ISSN 0306-9192, http://dx.org/10.1016/j.foodpol. 2017.02.004.

23. Republic of Kenya: Drought risk management and ending drought emergencies, Medium term plan $2013-$ 2017.

24. Rosegrant, Mark W.; Sulser, Timothy B.; Mason-D’Croz, Daniel; Cenacchi, Nicola; Nin- Pratt, Alejandro; Dunston, Shahnila; Zhu, Tingju; Ringler, Claudia; Wiebe, Keith D.; Robinson, Sherman; Willenbockel, Dirk; Xie, Hua; Kwon, Ho-Young; Johnson, Timothy; Thomas, Timothy S.; Wimmer, Florian; Schaldach, Rüdiger; Nelson, Gerald C.; and Willaarts, Barbara 2017. Quantitative foresight modeling to inform the CGIAR research portfolio. Project Report for USAID. Washington, D.C.: International Food Policy Research Institute (IFPRI). http://ebrary.ifpri.org/cdm/ref/collection/p15738coll2/id/131144

25. UN-Habitat (2008). State of the world cities 2008/09, United Nations Human Settlements Programme (UNHABITAT), Nairobi, Kenya.

26. World Bank. (2012). Carbon Sequestration in Agricultural Soils. Washington, DC. C) World Bank. https://openknowledge.worldbank.org/handle/10986/11868 License: CC BY 3.0 IGO.

27. World Bank. 2009. Africa - Making Development Climate Resilient: A World Bank Strategy for Sub-Saharan Africa. World Bank. (C World Bank. https://openknowledge.worldbank.org/handle/10986/3211 License: CC BY 3.0 IGO. 